\title{
GROWTH RESPONSE OF Sterculia setigera DEL. TO DIFFERENT TYPES OF FERTILIZERS AND WATERING REGIMES IN THE NURSERY
}

\author{
AIYELOJA A.A ${ }^{1^{*}}$ AND A.K. AZEEZ ${ }^{2}$ \\ ${ }^{1}$ Department of Forestry and Wildlife Mgt, University of Port Harcourt. Nigeria. \\ ${ }^{2}$ Department of Forestry, Oyo State Ministry of Agriculture and Natural Resources, \\ Nigeria. \\ * Corresponding author
}

\begin{abstract}
Growth response of Sterculia setigera to NPK (15:15:15) and Urea (46:0:0) at different levels of application and watering regimes were examined. A total of 160 seeds of Sterculia setigera were sown. After germination, 72 seedlings of good health and vigour were selected for the study. The fertilizers were applied at four different levels. $0.00 \mathrm{~g}, 0.67 \mathrm{~g}, 1.33 \mathrm{~g}$ and $2.0 \mathrm{~g}$ of NPK fertilizer and $0.00 \mathrm{~kg}, 0.22 \mathrm{~kg}, 0.44 \mathrm{~kg}$ and $0.66 \mathrm{~kg}$ of Urea with three replicates each. The second treatment was watering regimes; this was applied at three different levels, e.g. daily watering, watering at three days interval and watering at five days internal. The growth parameters which include total height, collar diameter, and number of leaves were measured for a period of twelve weeks. Biomass production was also evaluated. Assessment of the growth parameters reveals that when $0.20 \mathrm{~g}$ of NPK and $0.66 \mathrm{~kg}$ of Urea were applied under daily watering regime, the highest mean height of 23.82 and $24.39 \mathrm{~cm}$ were recorded. The highest mean diameter growth (collar) of 0.32 and $0.44 \mathrm{~cm}$ were equally observed when $0.20 \mathrm{~g}$ of NPK and $0.66 \mathrm{~kg}$ of Urea fertilizer were applied under daily watering regime. Also, the highest mean number of leaves was produced (6.12 and 6.72) when $0.20 \mathrm{~g}$ of NPK and $0.66 \mathrm{~kg}$ of Urea were applied. Biomass analysis from the study also indicates that $0.2 \mathrm{~g} N P K$ and $0.66 \mathrm{~kg}$ Urea gave the highest dry matter yield. Therefore, for optima production of Sterculia setigera in the nursery, $0.20 \mathrm{~g}$ of $N P K, 0.66 \mathrm{~kg}$ of Urea and daily watering regime are recommended.
\end{abstract}

Key words: Growth response, Sterculia setigera, fertilizer application, water regimes.

\section{INTRODUCTION}

Sterculia setigera is a member of the family Sterculiaceae. It is an indigenous soft wood tree species of a wider ecological adaptation, even though it is widely spread in Savanna areas of the tropical West Africa (Irvine, 1991). The distribution covers Nigeria, Cameroon, Senegal, Ghana and Cote devoir. In Nigeria, the species is found in all the Savanna areas of Oyo, Osun, Ondo and Ekiti, so also in Jigawa, Pleateau, Taraba, Kaduna, Kano and Sokoto state in the Northern guinea and Sudan Savanna area (Bada and Adeyoju, 1992)

The economic importance of the species includes carving, mat making, fuel wood and medical uses (Abbiw 1990). The species is of high economic value as it has a long fibre which makes it a close substitute to long fibre pine used for pulp and paper (RMRDC, 1997). The species has suffer a neglect in terms of harnessing its full economic potentials for pulp and paper making in our local industries because plantation establishment of the species is still at infant stage in Nigeria (Ogunwusi, 1997) Therefore intensive plantation establishment of this indigenous tree species will help in boosting the supply of raw material to the concerned industries and also go a long way at salvaging the nation the huge amount of money that might be spent annually on the importation of the exotic species for pulp and paper production. 
However, plantation establishment depend much on the supply of high vigour seedlings from nursery. Zeki (1995), reported that establishment of healthy trees in plantation and their management during the first phase (years) to achieve fast and early commencement of vegetative growth, have been found to be a very critical step in the life of all commercially grown species. Production of tree seedlings in the nursery depends largely among other factors, on the fertility of the nursery soil. Oni (2002) observed that soil is not uniform and a lot of variation could be observed within an area as small as one hectare. Thus a good soil that would support the plant growth should have adequate nutrient and water status. Fertilizers have been used to improve the nutrient status of the soil and also to accelerate seedlings growth in the nursery, in order to cut down the period required to obtain seedlings of transplantable size. Thus, the importance of organic and inorganic fertilizers in promoting the growth of both agricultural and forest crops cannot be over emphasized. Water plays important roles in the physiological activities of tree plants at both nursery and plantation stages. It dissolves the soil nutrients and helps in transportation of such nutrients from the soil to the other part of the plant. Water constitutes one of the basic requirements for plant growth (Dyck et al 1994).

Various research efforts have been made on the nutritional need of tree plant like Terminalia ivorensis (Aluko 1983 and 1987), Pinus Caribbean (Kadeba and Ajayi, 1986) Eucalyptus sp ( Fagbenro et al, 1987) and various other tree species. However, there is dearth of information specifically on the nutritional requirement of Sterculia setigera in terms of the type of fertilizer that is most suitable and the watering regime that is most adequate for raising its seedlings in the nursery. Considering the social economic of this species, ranging from pulp and paper production, mat making, domestic use as fire wood and medical uses, hence the need for this study. The study was therefore carried out to determine the response of the species to different types of fertilizer ,the species response to different water regimes and to ascertain the appropriate or best combinations among the fertilizer types and watering regimes, required for the optimum growth of the seedlings under nursery investigation.

\section{Experimental Site}

The experiment was carried out at the West African Hardwood Improvement Project (WAHIP) nursery of the Forestry Research Institute of Nigeria (FRIN) Jericho, Ibadan. The institute is located on Latitude $7^{\circ} 26^{1} \mathrm{~N}$ and Longitude $3^{\circ} 54^{1} \mathrm{E}$ of the equator.

\section{MATERIALS AND METHODS}

Materials used for the study include; seeds of Sterculia setigera which were sourced from FRIN gene bank. Other materials are Sterilized River sand, germination trays, top soil humidified propagator, NPK and Urea fertilizer, watering can, meter rule, vernier Caliper, sensitive electronic weighing balance, polythene bags, electronic oven and stationeries.

\section{Textural class: the major nutrients composition of the potting media.}

The top soil used as potting media was analyzed at the Rotas soil laboratory limited, Ring road, Ibadan. Table 1 contains the result of physical analysis of the top soil as well as its nutrient status before the commencement of the experiment. The physical analysis of the top soil shows its textural class to be sandy loam, while, Table 2 the nutrients analysis showed the nitrogen content of the top soil to be very low and $\mathrm{pH}$ slightly acidic. 160 seeds of Sterculia setigera obtained from the Forestry Research Institute of Nigeria were sown in the seed trays containing sterilized river sand. These were kept under humidified propagator to facilitate germination. After germination, 72 seedlings of good health and vigour were selected. These were transplanted into medium sized polypots $(14 \mathrm{~cm} \times 10 \mathrm{~cm} \times 10 \mathrm{~cm})$ which have been filled with top soil. The transplanting was done at three leaf stage. 
The first treatment applied were the types of fertilizer, namely NPK and urea. Each of these was applied at 4 different levels. The levels of application are as follows:

NPK $(15: 15: 15) \mathrm{q}_{0}-0.00 \mathrm{~kg}, \mathrm{q}_{1}-0.67 \mathrm{~g}, \mathrm{q}_{2}-1.33 \mathrm{~g}, \mathrm{q}_{3}-2.0 \mathrm{~g}$ (each per $2 \mathrm{~kg}$ of soil) Urea $(46: 0: 0) \mathrm{q}_{\mathrm{o}-} 0.00 \mathrm{~kg}, \mathrm{q}_{1-} 0.22 \mathrm{~kg}, \mathrm{q}_{2-} 0.44 \mathrm{~kg}, \mathrm{q}_{3}-0.66 \mathrm{~kg}$ (each per $2 \mathrm{~kg}$ of soil)

The second treatment applied was watering regimes. The applications are daily watering, watering at three days interval and watering at 5 days interval.

Biomass determination: The seedlings of Sterculia spp planted were uprooted after the twelfth week. Seedlings were lowered in the bowl of water for easy removal of soil particles attached to the root. The uprooted seedlings were separated into root, leaf and stem and the fresh weight were taken. These were then put into labeled envelope and oven dry for 48 hours at $80^{\circ} \mathrm{c}$. The samples were allowed to cool down and the dry weight were taken on electronic weighing balance

\section{Experimental Design}

The experiment was conducted using 3x3x3 factorial in CRD with 3 replicate.

Table 3 showed the experimental layout.

Table 3: experimental layout

\begin{tabular}{|c|c|c|}
\hline & $\begin{array}{llll}\text { F1 } & & \\
\mathrm{Q}_{\mathrm{o}} & \mathrm{q}_{1} & \mathrm{q}_{2}\end{array}$ & $\begin{array}{llll}\text { F2 } & & \\
\mathrm{Q}_{0} & \mathrm{q}_{1} & \mathrm{q}_{2}\end{array}$ \\
\hline $\mathrm{W}^{\mathrm{O}}$ & $\mathrm{W}_{\mathrm{o}} \mathrm{q}_{\mathrm{o}} \mathrm{W}_{\mathrm{o}} \mathrm{q}_{1} \mathrm{~W}_{\mathrm{o}} \mathrm{q}_{2} \mathrm{~W}_{\mathrm{o}} \mathrm{q}_{3}$ & $\mathrm{~W}_{\mathrm{o}} \mathrm{q}_{\mathrm{o}} \mathrm{W}_{\mathrm{o}} \mathrm{q}_{1} \mathrm{~W}_{\mathrm{o}} \mathrm{q}_{2} \mathrm{~W}_{\mathrm{o}} \mathrm{q}_{3}$ \\
\hline$W^{1}$ & $\mathrm{~W}_{1} \mathrm{q}_{\mathrm{o}} \mathrm{W}_{1} \mathrm{q}_{1} \mathrm{~W}_{1} \mathrm{q}_{2} \mathrm{~W}_{1} \mathrm{q}_{3}$ & $\mathrm{~W}_{1} \mathrm{q}_{\mathrm{o}} \mathrm{W}_{1} \mathrm{q}_{1} \mathrm{~W}_{1} \mathrm{q}_{2} \mathrm{~W}_{1} \mathrm{q}_{3}$ \\
\hline $\mathrm{W}^{2}$ & $\mathrm{~W}_{2} \mathrm{q}_{\mathrm{o}} \quad \mathrm{W}_{2} \mathrm{q}_{1} \quad \mathrm{~W}_{2} \mathrm{q}_{2} \mathrm{~W}_{2} \mathrm{q}_{3}$ & $\mathrm{~W}_{2} \mathrm{q}_{\mathrm{o}} \quad \mathrm{W}_{2} \mathrm{q}_{1} \quad \mathrm{~W}_{2} \mathrm{q}_{2} \mathrm{~W}_{2} \mathrm{q}_{3}$ \\
\hline
\end{tabular}

Where:

$F_{1}=$ NPK 15:15:15, $F_{2}=$ Urea 46:0:0

$\mathrm{q}_{\mathrm{o}}=$ Zero level of fertilizer application (control), $\mathrm{q}_{1=1} 1 \mathrm{st}$ level of fertilizer application

$\mathrm{q}_{2}=2^{\text {nd }}$ level of fertilizer application, $\mathrm{q}_{3}=3^{\text {rd }}$ level of fertilizer application

$\mathrm{W}_{\mathrm{o}}=1^{\text {st }}$ watering regime (normal daily watering), $\mathrm{W}_{1}=2^{\text {nd }}$ watering regime ( 3 days interval), $\mathrm{W}_{2}=3^{\text {rd }}$ watering regime ( 5 days interval), Normal daily watering $\left(\mathrm{W}_{\mathrm{o}}\right.$ ) also serves as a control experiment.

The statistical model used is

Yijk = N+Fi + Qj + Qij + Wk + FWik + QWjk + FQWijk + Eijk

Where :

Yijk = individual measurement of the experimental unit

$\mathrm{N}=$ general mean.

$\mathrm{Fi}=$ effect of factor $\mathrm{F}$ where $\mathrm{i}=1,2----\quad i$

$\mathrm{Qj}=$ effect of factor $\mathrm{Q}$ where $\mathrm{j}=.1,2$---- $\quad \mathrm{j}$

$\mathrm{Wk}=$ effect of factor $\mathrm{W}$ where $\mathrm{k}=1,2$----k

$(\mathrm{fw}) \mathrm{ik}=$ interaction effect of $\mathrm{f}$ and $\mathrm{w}$

$(\mathrm{Qw}) \mathrm{jk}=$ interaction effect of $\mathrm{Q}$ and $\mathrm{w}$

$(\mathrm{fQw}) \mathrm{ijk}=$ interaction effect of $\mathrm{f}, \mathrm{Q}$ and $\mathrm{w}$

Eijk = error associated with the individual measurement

The fertilizer were thoroughly mixed with soil and allowed to dissolve before transplanting Three watering regimes were applied to each block which was replicated 3 times. The watering regimes that were used are $\mathrm{W}_{\mathrm{o}}$ : daily watering, $\mathrm{W}_{1}$ :Watering once in 3 days, $\mathrm{W}_{2}$ :Watering once in 5 days . 


\section{Collection Of Data}

The following parameters were assessed fortnightly.

- Shoot height: this was measured in centimeters from the surface of the potting mixture to the terminal bud of the seedlings using a graduated ruler.

- Number of leaves: Total numbers of leaves per seedlings were visually counted.

- Collar diameter: this was measured using a venire caliper graduated in millimeters

- Leaf area: fully matured leaves plucked from the seedlings were traced on a graph sheet graduated in square centimeter and the area was determined by counting the number of complete squares in the area covered by the leaf.

\section{Growth Parameter}

The growth parameters of the seedlings of Sterculia setigera investigated in this study are total height colar diameter and leaf number.

\section{Total Heights}

The total heights of Sterculia setigera seedling were not significantly affected by the type of fertilizer used, the interactions between fertilizer type and watering regimes, as well as interaction between the fertilizer levels and watering regimes. However, fertilizer levels, watering regimes and interaction between fertilizer type and level of application as well as interaction between fertilizer type, level of applications and watering regimes had a marked effect on the total height of the seedling (Table 4). Though not significant different, when urea was used, the mean total height was 24.39 c, compared to $23.8 \mathrm{~cm}$ obtained when NPK was used. In term of fertilizer levels, the highest mean height of $26.83 \mathrm{~cm}$ was recorded when $\mathrm{q} 3(2.0 \mathrm{~g}$ NPK and $0.66 \mathrm{~kg}$ urea) of the fertilizers was applied, followed by $24.23 \mathrm{~cm}, 2.05 \mathrm{~cm}$ and $22.32 \mathrm{~cm}$ obtained when $1.33 \mathrm{~g} 0.44 \mathrm{~kg} 0.67 \mathrm{~g}, 0.22 \mathrm{~kg}$ and $0.00 \mathrm{~kg}, 0.00 \mathrm{~kg}$ of the fertilizer were applied respectively. Under varying moisture conditions, seedling that are watered daily gave the highest mean height of $26.68 \mathrm{~cm}$, followed by $24.10 \mathrm{~cm}$ and $21.55 \mathrm{~cm}$ obtained when watering was done once in 3 days and 5 days respectively. The graphical illustrations of the growth rate of seedlings for the period of 12-weeks were shown in figure 1, 2 and 3. in Figure 1 , the initial height of seedling raised with urea was higher but, at the sixth week to the end of the twelveth week the difference was not marked. In 2, though all the fertilizer levels enhanced the height of the seedling, the influence was much felt on seedling raised with $2.0 \mathrm{~g}$ $0.66 \mathrm{~kg}$ of the fertilizer. The total height growth rate as shown in figure 3 , showed that daily watering enhanced the growth of the seedling most.

\section{Collar Diameter}

Analysis of variance computed in table 4 showed that both NPK and urea had significant effect on the colar diameter of the seedlings. Also, the colar diameter of the seedling differed significantly $(\mathrm{p}<0.01)$ with variations in fertilizer levels, watering regimes and their interactions. However, the interactions between the fertilizer type, levels of application as well as the three watering regimes does not significantly influence colar diameters of the seedlings. Between the two fertilizers used, seedlings raised with urea have better diameter growth with the mean value of $0.44 \mathrm{~cm}$ per seedling ( Table 2, fig 4). When the fertilizer level was varied, the best diameter growth $(0.42 \mathrm{~cm})$ was observed in seedlings raised with $2.0 \mathrm{~g}$, $0.66 \mathrm{~kg}$ of the fertilizer, followed by $0.38 \mathrm{~cm}, 0.36 \mathrm{~cm}$ and $0.35 \mathrm{~cm}$ obtained when $1.33 \mathrm{~g}, 0.44$, $0.67 \mathrm{~g}, 0.22 \mathrm{~kg}$, and $2.0 \mathrm{~g} 0.66 \mathrm{~kg}$ of the fertilizer was applied per pot (table 5 , figure 5). However, the last three values were not significantly different ( at 5\% probability level). In terms of watering regimes, seedlings watered daily had the best diameter growth with mean value of $0.39 \mathrm{~cm}$, followed by $0.37 \mathrm{~cm}$ and $0.35 \mathrm{~cm}$ obtained when watering was done once in 
3 and 5 days respectively ( Table2). Meanwhile, the watering regimes on the colar diameter was not distract until the sixth week (Fig 6)

\section{Number Of Leaves}

Leaf production varied significantly $(\mathrm{p}<0.01)$ with difference in fertilizer and their level of application as well as watering regimes. Also the interactions between different levels of fertilizer application and watering regimes and, interactions between fertilizer types, level of application and watering regimes had significant effect on leaf production per seedling of Sterculia setigera ( Table 4)

Table 4: Analysis of variance of the growth parameter of the seedlings of Sterculia setigera

\begin{tabular}{|c|c|c|c|c|}
\hline Sources of variation & $\begin{array}{l}\text { Degree } \\
\text { of } \\
\text { freedom }\end{array}$ & Means of squares & F ratio & Significant level \\
\hline $\begin{array}{l}\text { Total height } \\
\text { Fertilizer type (FT) } \\
\text { Fertilizer level (FL) } \\
\text { Watering regime (WR) } \\
\text { FT x FL } \\
\text { FT x WR } \\
\text { FL x WR } \\
\text { FT x FL x WR } \\
\text { Error } \\
\text { Total }\end{array}$ & $\begin{array}{l}1 \\
3 \\
2 \\
3 \\
2 \\
6 \\
6 \\
48 \\
71\end{array}$ & $\begin{array}{l}35.0208 \\
422.9816 \\
949.6792 \\
198.4663 \\
43.6002 \\
59.0303 \\
173.3208 \\
35.9179\end{array}$ & $\begin{array}{l}0.9750 \\
11.7764 \\
26.4403 \\
5.5256 \\
1.2139 \\
1.6435 \\
4.8255\end{array}$ & $\begin{array}{l}\mathrm{ns} \\
* * \\
* * \\
* * \\
\mathrm{~ns} \\
\mathrm{~ns} \\
* *\end{array}$ \\
\hline $\begin{array}{l}\text { COLAR DIAMETER } \\
\text { Fertilizer type (FT) } \\
\text { Fertilizer level (FL) } \\
\text { Watering regime (WR) } \\
\text { FT x FL } \\
\text { FT x WR } \\
\text { FL x WR } \\
\text { FT x FL x WR } \\
\text { Error } \\
\text { Total }\end{array}$ & $\begin{array}{l}1 \\
3 \\
2 \\
3 \\
2 \\
6 \\
6 \\
48 \\
71\end{array}$ & $\begin{array}{l}1.5672 \\
0.0914 \\
0.1004 \\
0.0667 \\
0.1241 \\
0.0729 \\
0.0131 \\
0.0187\end{array}$ & $\begin{array}{l}83.6269 \\
4.8759 \\
5.3558 \\
3.5576 \\
6.6239 \\
3.8912 \\
0.6968\end{array}$ & $\begin{array}{l}* * \\
* * \\
* * \\
* * \\
* * \\
* * \\
\mathrm{~ns}\end{array}$ \\
\hline $\begin{array}{l}\text { LEAF NUMBER } \\
\text { Fertilizer type (FT) } \\
\text { Fertilizer level (FL) } \\
\text { Watering regime (WR) } \\
\text { FT x FL } \\
\text { FT x WR } \\
\text { FL x WR } \\
\text { FT x FL x WR } \\
\text { Error } \\
\text { Total }\end{array}$ & $\begin{array}{l}1 \\
3 \\
2 \\
3 \\
2 \\
6 \\
6 \\
48 \\
71\end{array}$ & $\begin{array}{l}39.1204 \\
85.3889 \\
73.2153 \\
9.2994 \\
5.8495 \\
22.4005 \\
11.0100 \\
3.9148\end{array}$ & $\begin{array}{l}9.9930 \\
21.8120 \\
18.7024 \\
2.3755 \\
1.4942 \\
5.7221 \\
2.8124\end{array}$ & $\begin{array}{l}* * \\
* * \\
* * \\
* \\
* * \\
* * \\
\mathrm{~ns}\end{array}$ \\
\hline
\end{tabular}

$*=$ significant at $5 \%$ probability level

$* *=$ significant $1 \%$ probability level

$$
\mathrm{ns}=\text { not significant }
$$

Like in total height and colar diameter, seedlings with urea had higher mean number of leaves per seedling (6.72) (Table 2). This difference became more pronounced in the fourth week to the end of the twelveth week (Fig 7). When the fertilizer levels was varied, the 
highest mean number of 7.66 leaves was produced per seedling raised with $2.0 \mathrm{~g} 0.66 \mathrm{~kg}$ of the fertilizer, followed by 6.46 and 5.81 and leaves per seedling raised with $1.33 \mathrm{~g}, 0.44 \mathrm{~kg}$, and $0.67 \mathrm{~g}, 0.22 \mathrm{~kg}$ of the fertilizer respectively. The least number of 5.74 was obtained on seedlings, raised with $0.67 \mathrm{~g}, 0.22 \mathrm{~kg}$ ( Table 5).

Table 5: Mean values of the growth parameter of the seedlings of Sterculia setigera

\begin{tabular}{|l|l|l|l|}
\hline \multicolumn{4}{|l|}{ Mean values } \\
\hline Variables & Total height $(\mathrm{cm})$ & Colar diameter $(\mathrm{cm})$ & Leaf number \\
\hline Fertilizer type & & & \\
NPK & $23.82 \mathrm{a}$ & $0.32 \mathrm{a}$ & $6.12 \mathrm{a}$ \\
Urea & $24.39 \mathrm{a}$ & $0.44 \mathrm{~b}$ & $6.72 \mathrm{~b}$ \\
\hline Fertilizer level & & & \\
$\mathrm{q}_{\mathrm{o}}$ & $22.32 \mathrm{a}$ & $0.35 \mathrm{a}$ & $5.74 \mathrm{a}$ \\
$\mathrm{q}_{1}$ & $23.05 \mathrm{ab}$ & $0.36 \mathrm{a}$ & $5.81 \mathrm{a}$ \\
$\mathrm{q}_{2}$ & $24.23 \mathrm{~b}$ & $0.38 \mathrm{a}$ & $6.46 \mathrm{~b}$ \\
$\mathrm{q}_{3}$ & $26.83 \mathrm{c}$ & $0.42 \mathrm{~b}$ & $7.66 \mathrm{c}$ \\
\hline Watering regimes & & & \\
Daily & & & $6.90 \mathrm{a}$ \\
Once in 3 days & $26.68 \mathrm{a}$ & $0.39 \mathrm{a}$ & $6.76 \mathrm{a}$ \\
Once in 5 days & $24.10 \mathrm{~b}$ & $0.37 \mathrm{~b}$ & $5.60 \mathrm{~b}$ \\
\hline
\end{tabular}

Note: Means with the same letter under the same column are not significant different from each other.

However, while leaf was more pronounced in seedlings raised with $2.0 \mathrm{~g}, 0.66 \mathrm{~kg}$ of the fertilizer throughout the 12 weeks of assessment, it was not significant among seedlings raised with $0.00 \mathrm{~kg}, 0.00 \mathrm{~kg}, 0.67 \mathrm{~g}, 0.22 \mathrm{~kg}$, and $2.0 \mathrm{~g}, 0.66 \mathrm{~kg}$ of the fertilizer because more significant (fig 8). Under different watering regimes, there was no significant difference in leaf number per seedling watered daily and once in 3-days despite the highest mean value of 6.90 obtained when watering was done once in 5-day. However, the rate of the leaf production per seedling was not marked until the fourth week when seedlings were watered daily and once in 3 days became distinct from those watered once in 5 days (Fig 5).

\section{Biomass Production}

The biomass production in the seedling of Sterculia setigera evaluated in this study are leaf dry weight, stem dry weight, root dry weight and total biomass.

\section{Leaf Dry Weight (LDW)}

The types of fertilizer used, level of application as well as the watering regimes significantly affect $(\mathrm{p}<0.01)$ the dry weight of the leaves of Sterculia setigera. Also significant are the interactions between fertilizer types and their levels, fertilizer types and watering regimes, level of fertilizer application and watering regimes, as well as the interaction between the type of fertilizer used, level of application and the watering regimes ( Table 5 and 6)

The mean values in Table 7 showed that seedlings raised with urea produced higher leaf dry weight of $1.91 \mathrm{~g}$ per seedling compared to $1.10 \mathrm{~g}$ produced when NPK was applied. With varying level of fertilizer applications, seedlings raised with $2.0 \mathrm{~g}, 0.66 \mathrm{~kg}$ of the fertilizer had the highest mean LDW value of $2.85 \mathrm{~g}$, followed by seedling raised with $1.33 \mathrm{~g}$, $0.44 \mathrm{~kg}$, and $0.67 \mathrm{~g}, 0.22 \mathrm{~kg}$ of the lowest mean value of $0.55 \mathrm{~g}$ was obtained per seedling raised with $0.00 \mathrm{~kg}, 0.00 \mathrm{~kg}$ of the fertilizer. 
The graphical illustration in figure 10 showed that the responded positively to leave dry weight, but the difference between the two fertilizers was not marked except in seedling raised with $2.0 \mathrm{~g}, 0.66 \mathrm{~kg}$ of the fertilizer where the leaf dry weight of per seedling raised with urea was more than doubled those raised with $2.0 \mathrm{~g}, 0.66 \mathrm{~kg}$ of NPK fertilizer.

\section{Stem Dry Weight (SDW)}

The stem dry weight of Sterculia setigera seedling were significant influenced $(\mathrm{p}<0.01)$ by the fertilizer type, level of application and watering regimes. Similarly, the interactions between the fertilizer types and their level of fertilizer type and watering regimes , as well as the interactions between fertilizer type, level of applications and watering regimes had significant effect $(\mathrm{p}<0.01)$ on the stem dry weight per seedling ( table 6)

Meanwhile, the seedlings raised with urea had higher stem dry weight with mean value of $1.04 \mathrm{~g}$ per seedlings. Also, there was variation among seedlings raised with different levels of the fertilizer (Table 7). The highest means of $1.10 \mathrm{~g}$ was obtained where $\mathrm{q}_{3}$ of the fertilizer per applied. This was closely followed by $0.86 \mathrm{~g}$ and $0.78 \mathrm{~g}$ per seedling raised with $1.33 \mathrm{~g}, 0.44 \mathrm{~kg}$ and $0.67 \mathrm{~g}, 0.22 \mathrm{~kg}$ of the fertilizers respectively. The least value, $0.68 \mathrm{~g}$ was obtained per seedling raised with $0.00 \mathrm{~kg}, 0.00 \mathrm{~kg}$ of applied urea enhanced stem dry weight more than NPK particularly when $2.0 \mathrm{~g}, 0.66 \mathrm{~kg}$ of the fertilizer was applied (fig 11)

Meanwhile, when the watering regime was varied, seedlings watered daily had the highest stem dry weight of $1.23 \mathrm{~g}$. The value was significant when compared with the mean stem dry weight of $0.67 \mathrm{~g}$ per seedling watered once in 3 and 5 day (Table 7)

\section{Stem Dry Weight (SDW)}

The stem dry weight of Sterculia setigera seedling were significant influenced $(p<0.01)$ by the fertilizer type, level of application and watering regimes. Similarly, the interactions between the fertilizer types and their level of fertilizer type and watering regimes , as well as the interactions between fertilizer type, level of applications and watering regimes had significant effect $(\mathrm{p}<0.01)$ on the stem dry weight per seedling ( table 6). Meanwhile, the seedlings raised with urea had higher stem dry weight with mean value of $1.04 \mathrm{~g}$ per seedlings. Also, there were variations among seedlings raised with different levels of the fertilizer (Table 7). The highest means of $1.10 \mathrm{~g}$ was obtained where $\mathrm{q}_{3}$ of the fertilizer per applied. This was closely followed by $0.86 \mathrm{~g}$ and $0.78 \mathrm{~g}$ per seedling raised with $1.33 \mathrm{~g}, 0.44 \mathrm{~kg}$ and $0.67 \mathrm{~g}, 0.22 \mathrm{~kg}$ of the fertilizers respectively. The least value, $0.68 \mathrm{~g}$ was obtained per seedling raised with $0.00 \mathrm{~kg}, 0.00 \mathrm{~kg}$ of applied urea enhanced stem dry weight more than NPK particularly when $2.0 \mathrm{~g}, 0.66 \mathrm{~kg}$ of the fertilizer was applied (fig 11)

Meanwhile, when the watering regimes were varied, seedlings watered daily had the highest stem dry weight of $1.23 \mathrm{~g}$. The value was significant when compared with the mean stem dry weight of $0.67 \mathrm{~g}$ per seedling watered once in 3 and 5 day (Table 7)

Table 6: Analysis of biomass production in seedling of Sterculia setigera

\begin{tabular}{|c|c|c|c|c|}
\hline $\begin{array}{ll}\text { Sources } & \text { of } \\
\text { variation } & \end{array}$ & $\begin{array}{l}\text { Degree of } \\
\text { freedom }\end{array}$ & $\begin{array}{ll}\text { Means } & \text { of } \\
\text { squares }\end{array}$ & F ratio & $\begin{array}{l}\text { Significant } \\
\text { level }\end{array}$ \\
\hline $\begin{array}{ll}\text { LEAF } & \text { DRY } \\
\text { WEIGHT } & \end{array}$ & & & & \\
\hline $\begin{array}{l}\text { Fertilizer type } \\
\text { (FT) }\end{array}$ & 1 & 11.9479 & 523.552 & $* *$ \\
\hline $\begin{array}{l}\text { Fertilizer level } \\
\text { (FL) }\end{array}$ & 3 & 17.2921 & 757.732 & $* *$ \\
\hline $\begin{array}{l}\text { Watering regime } \\
\text { (WR) }\end{array}$ & 2 & 22.9734 & 1006.684 & $* *$ \\
\hline FT $\times$ FL & 3 & 22.4058 & 981.812 & $* *$ \\
\hline FT x WR & 2 & 4.0074 & 175.604 & $* *$ \\
\hline FL $x$ WR & 6 & 6.4067 & 280.739 & $* *$ \\
\hline
\end{tabular}


Journal of Agriculture and Social Research (JASR) VOL. 10, No. 1, 2010

\begin{tabular}{|c|c|c|c|c|}
\hline $\begin{array}{l}\text { FT x FL x WR } \\
\text { Error } \\
\text { Total }\end{array}$ & $\begin{array}{l}6 \\
48 \\
71\end{array}$ & $\begin{array}{l}9.2277 \\
0.0228\end{array}$ & 404.354 & $* *$ \\
\hline $\begin{array}{lr}\text { STEM } & \text { DRY } \\
\text { WEIGHT } & \\
\text { Fertilizer } & \text { type } \\
\text { (FT) } & \\
\text { Fertilizer } & \text { level } \\
\text { (FL) } & \\
\text { Watering } & \text { regime } \\
\text { (WR) } & \\
\text { FT x FL } & \\
\text { FT x WR } & \\
\text { FL x WR } \\
\text { FT x FL x WR } \\
\text { Error } \\
\text { Total }\end{array}$ & $\begin{array}{l}3 \\
2 \\
3 \\
2 \\
6 \\
6 \\
48 \\
71\end{array}$ & $\begin{array}{l}2.4902 \\
4.3754 \\
2.8948 \\
3.2777 \\
3.0472 \\
0.0012\end{array}$ & $\begin{array}{l}2013.224 \\
473.525 \\
2046.714 \\
\\
3596.198 \\
2379.289 \\
2693.997 \\
2504.578\end{array}$ & $\begin{array}{l}* * \\
* * \\
* * \\
* * \\
* *\end{array}$ \\
\hline $\begin{array}{lr}\text { ROOT } & \text { DRY } \\
\text { WEIGHT } & \\
\text { Fertilizer } & \text { type } \\
\text { (FT) } & \\
\text { Fertilizer } & \text { level } \\
\text { (FL) } & \\
\text { Watering } & \text { regime } \\
\text { (WR) } & \\
\text { FT x FL } & \\
\text { FT x WR } & \\
\text { FL x WR } & \\
\text { FT x FL x WR } \\
\text { Error } \\
\text { Total }\end{array}$ & $\begin{array}{l}3 \\
2 \\
3 \\
2 \\
6 \\
6 \\
48 \\
71\end{array}$ & $\begin{array}{l}22.1090 \\
10.1946 \\
4.7536 \\
\\
15.8676 \\
6.8338 \\
4.9768 \\
7.5664 \\
0.1206\end{array}$ & $\begin{array}{l}183.9897 \\
84.8385 \\
39.5593 \\
132.0488 \\
56.8704 \\
41.4168 \\
62.9667\end{array}$ & $\begin{array}{l}* * \\
* * \\
* \\
* * \\
* * \\
* *\end{array}$ \\
\hline $\begin{array}{ll}\text { TOTAL } & \text { DRY } \\
\text { BIOMASS } & \\
\text { Fertilizer } & \text { type } \\
(\text { FT) } & \\
\text { Fertilizer } & \text { level } \\
\text { (FL) } & \\
\text { Watering } & \text { regime } \\
\text { (WR) } & \\
\text { FT x FL } & \\
\text { FT x WR } \\
\text { FL x WR } \\
\text { FT x FL x WR } \\
\text { Error } \\
\text { Total }\end{array}$ & $\begin{array}{l}3 \\
2 \\
3 \\
2 \\
6 \\
6 \\
48 \\
71\end{array}$ & $\begin{array}{l}69.7577 \\
150.7664 \\
27.1450 \\
30.6825 \\
41.0065 \\
6.8627 \\
13.4459 \\
0.036744\end{array}$ & $\begin{array}{l}1898.457 \\
4348.043 \\
738.750 \\
\\
835.024 \\
1115.993 \\
186.770 \\
365.931\end{array}$ & $\begin{array}{l}* \\
* * \\
* * \\
* *\end{array}$ \\
\hline
\end{tabular}


Between the two fertilizer, seedling raised with urea had higher mean root dry weight of $2.09 \mathrm{~g}$ compared with $0.98 \mathrm{~g}$ obtained when NPK was used ( Table 7). Among the four fertilizer levels seedlings raised with $\mathrm{q}_{3}$ of fertilizers $(0.20 \mathrm{~g}$ NPK and $0.66 \mathrm{~kg}$ Urea) had the highest mean root dry weight of $2.50 \mathrm{~g}$ per seedling followed by $1.69 \mathrm{~g}$ and $1.22 \mathrm{~g}$ obtained per seedling raised with $1.33 \mathrm{~g} 0.44 \mathrm{~kg}$ and $0.67 \mathrm{~g}, 0.22 \mathrm{~kg}$ of the fertilizer respectively

The least, $0.73 \mathrm{~g}$, root dry weight per seedling was obtained when $0.00 \mathrm{~kg}, 0.00 \mathrm{~kg}$ of the fertilizer was applied (Table 7). In Figure 12, the root weight per seedling raised with urea was visibly higher than those raised with NPK. It became most pronounced when $2.0 \mathrm{~g}$, $0.66 \mathrm{~kg}$ of the fertilizer was compared. The variation in watering regimes also had significant effect on mean root dry weight of Sterculia setigera. Seedling watered once in 5 days had highest mean value of $1.86 \mathrm{~g}$ per seedling though not significantly differentiated from $1.71 \mathrm{~g}$ obtained when watering was done once in 3 days. The least mean value of $1.03 \mathrm{~g}$ was obtained in seedling watered daily (Table 7)

\section{Total Dry Biomass}

In Table 4, analysis of variance showed that both fertilizer type and level of application as well as watering regimes had significant effect $(\mathrm{p}<0.01)$ on total dry biomass of the seedlings. Similarly, the interactions between fertilizer type and level of application, fertilizer type and watering regimes and, between fertilizer levels and watering regimes as well as the interactions between fertilizer type, level of application and watering regimes ( Table 7). Between the two fertilizers, seedlings raised with urea had higher total dry biomass, $4.69 \mathrm{~g}$ per seedlings compared with $2.72 \mathrm{~g}$ per seedling raised with NPK. Among the four fertilizer level $2.0 \mathrm{~g} 0.66 \mathrm{~kg}$ of the fertilizer produced the highest mean total dry biomass of $7.83 \mathrm{~g}$ per seedling followed by a distance $3.76 \mathrm{~g}$ and $2.52 \mathrm{~g}$ obtained when $1.33 \mathrm{~g}, 0.44 \mathrm{~kg}$ and $0.67 \mathrm{~g}$, $0.22 \mathrm{~kg}$ of the fertilizer was applied respectively. The least, $0.96 \mathrm{~g}$ TDB was obtained when $0.00 \mathrm{~kg}, 0.00 \mathrm{~kg}$ of the fertilizer was applied. The difference between the seedlings raised with urea and NPK was most pronounced when the fertilizers was compared (fig 13)

Under the three moisture conditions daily watering enhanced the total biomass most with the mean value of $4.83 \mathrm{~g}$ per seedling followed by $3.56 \mathrm{~g}$ and $2.72 \mathrm{~g}$ obtained in per seedling watered once in 5 days and 3 days respectively (table 7)

Means values of the biomass production in the seedlings of Sterculia setigera

\begin{tabular}{|l|l|l|l|l|}
\hline \multicolumn{5}{|l|}{ Mean values } \\
\hline Variables & $\begin{array}{l}\text { Leaf dry weight } \\
(\mathrm{g})\end{array}$ & $\begin{array}{l}\text { Stem dry weight } \\
(\mathrm{g} 0\end{array}$ & $\begin{array}{l}\text { Root dry weight } \\
(\mathrm{g})\end{array}$ & $\begin{array}{l}\text { Total dry } \\
\text { biomass }(\mathrm{g})\end{array}$ \\
\hline $\begin{array}{l}\text { Fertilizer type } \\
\text { NPK }\end{array}$ & $1.10 \mathrm{a}$ & $0.67 \mathrm{a}$ & $0.98 \mathrm{a}$ & $2.72 \mathrm{a}$ \\
Urea & $1.91 \mathrm{~b}$ & $1.04 \mathrm{~b}$ & $2.09 \mathrm{~b}$ & $4.69 \mathrm{~b}$ \\
\hline Fertilizer level & & & & \\
$\mathrm{q}_{\mathrm{o}}$ & $0.55 \mathrm{a}$ & $0.68 \mathrm{a}$ & $0.73 \mathrm{a}$ & $0.96 \mathrm{a}$ \\
$\mathrm{q}_{1}$ & $1.10 \mathrm{~b}$ & $0.78 \mathrm{~b}$ & $1.22 \mathrm{~b}$ & $2.25 \mathrm{~b}$ \\
$\mathrm{q}_{2}$ & $1.51 \mathrm{c}$ & $0.86 \mathrm{c}$ & $1.69 \mathrm{c}$ & $3.76 \mathrm{c}$ \\
$\mathrm{q}_{3}$ & $2.85 \mathrm{~d}$ & $1.10 \mathrm{~d}$ & $2.50 \mathrm{~d}$ & $7.83 \mathrm{~d}$ \\
& & & & \\
\hline Watering & & & & \\
regimes & $2.61 \mathrm{a}$ & $1.23 \mathrm{a}$ & $1.03 \mathrm{a}$ & $4.83 \mathrm{a}$ \\
Daily & $1.13 \mathrm{~b}$ & $0.67 \mathrm{~b}$ & $1.71 \mathrm{~b}$ & $2.25 \mathrm{~b}$ \\
Once in 3 days & $0.76 \mathrm{c}$ & $0.67 \mathrm{~b}$ & $3.56 \mathrm{c}$ \\
Once in 5 days & & & & \\
\hline
\end{tabular}


Note: Means with the same letter under the same column are not significant different from each other.

\section{Correlation Analysis Of Growth Parameters And Biomass Production}

The correlation analyses employed in this study to test the degree of relationship between the parameter investigated indicated that significant relationship existed between the growth parameters ( total height, colar diameter and leaf number in one hand and between dry weight parameter ( leaf, stem, root and total biomass) on the other hand. For example in Table 8 when the parameters was compared, it was discovered that the best relationship $(40.5 \%)$ existed between the total height of the seedlings and their colar diameters as against $31.5 \%$ and $27.5 \%$ correlation that existed between total height and leaf number, and colar diameter and leaf number respectively

Similarly, when the biomass production parameters were compared, it was discovered that there were significant correlation among the parameters. When ranking was done, the correlation between root dry weight and total dry biomass ranked highest contributing $20.5 \%$ $\mathrm{f}$ the total, followed by $20.1 \%$ that existed between leaf dry weight and total biomass. The least correlation, $11.5 \%$ was observed between stem dry weight and leaf dry weight.

: Correlation analysis of the growth parameter of the seedlings of Sterculia setigera

\begin{tabular}{|l|l|l|l|}
\hline Growth parameter & Total height & Colar diameter & Leaf number \\
\hline $\begin{array}{l}\text { Total height } \\
\text { Colar diameter }\end{array}$ & $40.5 \%$ & $0.45^{*}$ & $0.35^{*}$ \\
Leaf number & $31.5 \%$ & & \\
\end{tabular}

$*=$ significant at $5 \%$ probability level

Table 9: Correlation analysis of the biomass production in the seedlings of Sterculia setigera.

\begin{tabular}{|l|l|l|l|l|}
\hline & \multicolumn{4}{|l|}{ Variables } \\
\hline Variables & LF-DR-WT & ST-DR-WT & RT-DR-WT & T-DR-WT \\
\hline LF-DR-WT & & $0.55^{*}$ & $0.93^{*}$ & $0.96^{*}$ \\
ST-DR-WT & $11.5 \%$ & & $0.63^{*}$ & $0.72^{*}$ \\
RT-DR-WT & $19.5 \%$ & $13.2 \%$ & & $0.98^{*}$ \\
T-DR-WT & $20.1 \%$ & $15.1 \%$ & $20.5 \%$ & \\
\hline
\end{tabular}

\section{CONCLUSION}

It has been the aim of this study of determine the growth response of Sterculia setigera seedlings to NPK (15:15:15) and Urea (46:0:0) with varying levels of application and watering regimes. Bearing in mind that the success of any plantation establishment is to a great extent dependent on the availability of healthy and vigorously growing transplantable seedlings raised in suitable potting medium, this goal remained clear throughout this study.

The findings from this study showed that nursery seedlings of Sterculia setigera a seedlings responded positively to urea ad NPK fertilizer. Accordingly both fertilizer types enhanced the growth parameters and biomass production yields differently. Under varing fertilizer levels, the best growth parameter, total height $(26.83 \mathrm{~cm})$ colar diameter $(0.45 \mathrm{~cm})$ and leaf number (7.66) and their dry weight; leaf $(2.85 \mathrm{~g})$, stem $(1.10 \mathrm{~g})$, root $(2.50 \mathrm{~g})$ and total biomass $(7.83 \mathrm{~g})$ per seedling was observed when NPK and urea levels were raised to $0.20 \mathrm{~g}$ and $0.66 \mathrm{~kg}$ per pot respectively.

Between the two fertilizers, seedlings raised with urea performed better throughout the twelve weeks period of assessment especially, when seedlings raised with $0.20 \mathrm{~g}$ of NPK and $0.66 \mathrm{~kg}$ of urea fertilizers was compared. 
Journal of Agriculture and Social Research (JASR) VOL. 10, No. 1, 2010

Lastly, at varying watering regimes, Sterculia setigera seedlings performed best when watering was done daily. 


\section{RECOMMENDATIONS}

Consequent upon the findings and conclusions drawn from this study, the following recommendations are made;

- Preference should be given to urea over NPK fertilizer in raising seedlings of Sterculia setigera

- $0.66 \mathrm{~kg}$ of urea (46:0:0) should be applied for pot to ensure maximum growth and biomass production

- Where urea is not available, $0.20 \mathrm{~g}$ of NPK should be applied instead.

- Watering of the seedlings of Sterculia setigera seedlings should be carried out daily.

- Further research on the appropriate level of NPK and urea for raising seedlings of Sterculia setigera should be encouraged. However, the application rate should be above $0.2 \mathrm{~g}$ of NPK and $0.66 \mathrm{~kg}$ of urea. This is with the aim the ascertaining of optimal level of these fertilizers for raising the seedlings of Sterculia setigera.

\section{REFERENCES}

Abbiw, D.K (1990). Useful plans of Ghana. Intermediate publication and the royal botanic gardens $337 \mathrm{p}$

Abimbola O.A, Udoh, F and Ademola A.M (2001). Fundamental of Agricultural science for colleges. 35-36pp

Aluko A.P and Aduayi, E.A (1984). Influence of nitrogen and phosphorus supply in establishment of Terminalia Spp. Nig jour of science vol. 20

Anderson H. W and Gassel, S.P (1996). Effect of nursery fertilization on out planted Gongles. Jour of for 64 109-112 spp.

Bada S.O (1990). The influence of forest management on the wood quality of native species. Jour. Of tropical forest Res. Vol. 5 and 6 54-61pp

Bada, S.O and Adeyoju S.K (1992). Social economic survey of the use of Sterculia setigera Del. A potential agroforestry species in Nigeria. International work management in Africa, kampala, Uganda. 45-60 pp

Bechlard, E.P (1986): Effect of soil moisture stress on the growth of seedlings of three Eucalyptus species. Australian for. Res. Vol. 16:51-61

Chijioke E.O (1978). Soil site factor in relation to growth and wood quality of Gmelina aborea in western Nig. Ph.d. Thesis, University of Ibadan (unpublished)

Cook R.L and Ellis, B.G (1192). Soil management. A word view conservation and productivity. Krieger publisher.

Daker , W.M (1965). The carry over effect of fertilizer applied to tube nursery stock of callitris intratropical Aust. For Res. 1(3): 40-42 pp.

Elmerl, L.c (1990). Agric. Science fundamental and applications Delmar publisher Inc. 102$103 \mathrm{pp}$.

Fagbenro J. A (1989) comparative effect of Nigeria. Lignite poultry manure, cow Dung and inorganic fertilizer on the growth of Gmelina arborea seedlings. FAN proceedings 1989 p. 83

Forth, H.d (1978). Fundamental of soil science $6^{\text {th }}$ edition, John Walley and sons Inc. New York 410 pp.

Grunwald C.a dn karschon, R (1982): Leaf xylem water potentials and water saturation deficits as related to seed origin of Eucalyptus Camaldulensis. Dehn Australian for. Res. Vol 12 pp 175-181

Guantian, Y; Huangcan, X and Weiliang Z. (1997) Fertilizer application and seedling growth of Daemonorops margaritae. Forest Research 3(1): 90-94

Hartman and Kester (1993). Plant propagation, principles and practices. $6^{\text {th }}$ edition. (international) 
Hopkins B. (1977). Forest Savanna. Heineman Educational book Ltd. 110-170 oo,

Irvine F.R. (1991). Woody plants of Ghana with special reference to their uses. Revise edition: Oxford University Press London 178-179 pp.

Kadeba o. (1978). Nutritional aspect of afforestation with exotic tree species - in savanna region of Nigeria com. For Rev. 57: 191-199

Kadeba O. (1986). Nutrient in relation to forest in Nig. P. 109. Queensland Agricultural Journal, Australia.

Keay R.W.J Onochie, C.F.A and Stanfield D.P (1987) Nigerian trees. Vol. 1. 447 p

Maaikuhuri, R.K and Semwal, R.L (1997): Agroforestry for rehabilitation of degraded community lands. A case study in the Garhwal Hamalaya, India. International Tree Crops Journal. Vol 9:91-107

Nwoboshi, L.C (1982): Tropical silviculural principles and techniques. Ibadan University press $333 \mathrm{pp}$

Nwoboshi, L.C (1973): Studies on mineral nutrition of teak (Tectora randis L.F) Ph.d Thesis, University of Ibadan. $388 \mathrm{pp}$.

Nwoboshi, L.C (1987): potential productivity index as a basis for soil evaluation in plantation forestry. J. Trop. Forest Resources 3:30-41

Nwoboshi, L.C (2000): The nutrient factor in sustainable forestry. Ibadan University Press. $303 p$

Ogunwusi, A.A (1997) wood properties of Sterculia setigera in the savanna belt of Nigeria. Nig Jour. Of for. Vol. $27(1 \& 2)$

Ola, B.M. (2003). Specific gravity and extractive content in the wood of plantation grown Sterculia setigera Del. M.Sc. Thesis University of Ibadan. (unpublished)

Ong , K.H. (1995): Response of sentang (Azadirachta excelsa (Jack) to nutrient stress. B.c (for) Thesis, University pertainian Malaysia, serdang.

Oni, O and Caspa, R.G (2002). Effect of soil sources and pot sizes on the early growth of seedlings of an indigenous multipurpose tree species (Parkia biglobosa) Nig. Journal of ecology. Vol 4 (1)

Oni, O and Gbadamosi, A.e (2000): Effects of provenance and watering regimes on the growth of seedlings to Triplochiton scleroxylon (K. Schum). The Bioprospector vol. 2. September 2000. 107-130

Sleh, J. B (2003): Effects of oranic and inorganic fertilizers on the growth of Tectona grandis (Teak) seedlings M.sc . Thesis University of Ibadan. (Unpublished 80p.

Zainudin, S.R; Awang, K. and hanif, A.H (2003): Effects of combined nutrient and water stress on the growth of Hopea odorata ( Roxb) and Mimusops elengi : (Linn) seedlings. Journal of Arboriculture. March 2003. 29(2): 79-83 